\title{
Countering Radicalism in the North Caucasus
}

\author{
Ivan A. Babin, Anton Chablin, Aleksei Kazantsev, Moham- \\ med A. Khesham, and Yuri V. Vasiliyev
}

\section{Compiled and edited by Frederic Labarre}

\begin{abstract}
This article is an abridged version of the proceedings of the PfP Consortium's Conflict Studies Working Group (CSWG) workshop which took place in Berlin, 7-9 November 2016. The workshop, entitled "Countering Radical Islamism in the North Caucasus" welcomed representatives of Germany, Poland, Romania, Russia, including of course the North Caucasus. It was organized by the PfP Consortium at the behest of Ivan A. Babin, director of the Center for Scientific and Social Innovation (Stavropol, Russia) and Baron Udo von Massenbach, president of the German-American Business Association. Carmen Rijnoveanu presided the conference.

The workshop's aim was to highlight the gravity of Islamic radicalization in the North Caucasus, and treat it as a symptom of wider geopolitical and social upheavals worldwide. In putting the accent on the scope of the challenge, our Russian guests were also stressing that the successful defeat of movements like DAESH requires East-West cooperation.

This cooperation should help open dialogue between the great powers in our Ukraine and Syria-fueled "Cold War." Urgency and cooperation are some of the themes that motivate each presentation in the workshop. This paper has collected presentations that were representative of its intent. They are presented here translated and edited, with the understanding that the opinions they represent are those of the authors only, and in no way reflect that of any government or organization. Each piece is identified by its proponent, and all the pieces are interspersed with short commentaries designed to bring unity to the whole document.
\end{abstract}

Keywords: Caucasus, terrorism, radicalism, Islamism, religion, civil society, mass media. 


\section{THE MASS MEDIA AS COUNTER-IDEOLOGY TOOL Anton Chablin}

According to the Central Intelligence Agency $(\mathrm{CIA})$, there are approximately 31000 fighters in the ISIS ranks in Iraq and Syria at the present moment. By comparison, Al Qaeda had 3000 at its peak. On the side of regular national forces, this is nearly half of the U.S. Marine Corps' strength and a little less than half of the total Canadian armed forces (all elements combined).

Comparison with established armies is pertinent because ISIS aims at statehood, and had an economy. In effect, it is worth about 2 billion USD, and can count on 2-3 million USD daily in oil revenues, for it controls oil fields and small refineries, the product of which is sold through Turkey. ${ }^{1}$ Such revenues allow it to attract foreign fighters by paying them anywhere from 1000 to 4500 USD a month. These are powerful numbers, difficult to beat by Russian and North Caucasus economies especially. It is not surprising that the second most important point of origin of foreign fighters is Russia.

Economic incentivization is an important enabler of radicalism, and one which gravely complicates the task of the police and intelligence services, since "profiling" thereby becomes unreliable. Thus, 26-year-old Shamil Abdulazizov, a religious neophyte without education or career prospects nevertheless underwent terrorism training Syria. Meanwhile, Marlud Kerimov, 21, was a promising medical student from a non-religious family whose members had important functions in local and state-level security apparatuses. A third case is Beslan Medaev, a North Caucasus University Law Faculty graduate with a promising career as an attorney. He and his wife trekked through Chechnya to get to Syria, where he became an invalid. Socio-economic conditions are therefore a powerful explanatory tool for the choices made by would-be radicals.

1 The idea that ISIS is actively seeking statehood is part of the ISIS mythology and recruitment appeal. Whether it needs statehood to survive is a matter of debate. However, there is evidence that there is correlation between the group's revenue and the control of territory. As a result, military effort has been pursuing a two-objective strategy of curtailing revenue generation (mainly oil and gas related) and territorial control by the group. Latest figures of monthly revenue for ISIS appear to be some 4 million USD, down from 45 million USD in 2015, according to some sources. For more insights, see Erika Solomon, Guy Chazan and Sam Jones, "ISIS Inc.: How Oil Fuels the Jihadi Terrorists," Financial Times, October 15, 2015, www.ft.com/content/b8234932-719b11e5-ad6d-f4ed76f0900a, and Ahmet S. Yayla and Colin P. Clarke, "Turkey's Double ISIS Standard," Foreign Policy, https://foreignpolicy.com/ 2018/04/12/turkeysdouble-isis-standard/, as well as Mara Revkin and Jacob Olidort, "Does ISIS Need Territory to Survive?" New York Times Room for Debate, October 26, 2016, www.nytimes.com/roomfordebate/2016/10/21/does-isis-need-territory-to-survive; and Bennett Seftel interviewing Patrick Johnston: "Oil, Extortion Still Paying Off for ISIS," TheRANDBlog (RAND Corporation, 27 October 2017), www.rand.org/blog/ 2017/10/oil-extortion-still-paying-off-for-isis.html. All sources consulted on September 28, 2018. 
Another enabling factor is the influence prevalent and attractive-if not addictive-social media. Robert Herrigan, director of the United Kingdom's GCHQ, claims that social media has become the command and control network of terrorists. The space lacks here to explain the mechanisms of how social media affects behavior. However, it is nevertheless possible to presume that individuals can be receptive to positive messaging, and be led away from terrorist activities regardless of social conditions. Positive messaging, including public praise and recognition for those who have chosen NOT to join ISIS, is one method.

The Center for Scientific and Social Innovation supports and reports on activities that it and other non-governmental organizations carry out, highlighting the positive example of young people deaf to ISIS' siren call. In parallel, the Center assiduously informs its audience of the negative physical, legal and social consequences of yielding to self-radicalization.

However, local think thanks and even large government agencies do not have the means that ISIS can deploy. Therefore, defeating radical Islamism by ISIS' own devices will not be accomplished by stylish counter-propaganda alone. The challenge posed by radicalism requires concerted and combined efforts by many actors and countries. We argue here that the urgency is sufficiently great for geopolitical adversaries to join forces.

\section{THE AIM OF COUNTERING RADICAL ISLAMISM AMONG THE YOUTH OF THE NORTH CAUCASUS}

\section{Ivan A. Babin}

Analyses made by our "Center for Scientific and Social Innovation" in Stavropol show that the religious factor plays a role in activating the extremist behavior of young people. But it would be erroneous to consider that the phenomenon of "Islamic radicalism" is entirely determined by religious reasons. "Islamic radicalism" is aggravated by the fact that the usual expressions of protest over difficult material conditions and social injustice, along with manifestations of criminality, find a religious justification in youth consciousness. It is no accident that in the North Caucasus today there is intense attention devoted to the religious and ideological indoctrination of the younger generation by Islamist leaders.

Radical Islamic leaders, trying to legitimize and de-secularize social relations, tend to exaggerate the role of the religious factor in the protest actions of young people. Thus, they are trying to open new opportunities for strengthening the processes of radicalization of the youth of the North Caucasus. Three approaches help mitigate youth radicalization in the North Caucasus: 1 ) we must emphasize the aggressive and volatile nature of religious extremism, in particular of radical Islam; 2) it is important to take into account the peculiarities and complexities of the regions of the North Caucasus, and 3) we must understand how the internet and social networks increase self-radicalization of young people.

There are further factors to consider. To begin with, the external factorspolitical, ideological and socio-economic conditions of youth radicalization- 
need to be considered. Alongside those are the "internal" factors, which are just as important, if not more. Particular attention must be paid to local history and culture, to the quality of interaction among communities on the one hand, and with the authorities on the other. Also, the role of diaspora youth leaders and of ethno-confessional associations cannot be ignored.

Second, the creation of formal, recognized and legitimate local institutions and systems whose task is to counteract and eliminate the influence of aggression and conflict is recommended and encouraged. The objective of such institutions should be to discredit extremist narrative, muffle publications, literature and material promoting social agitation, in hard copy or online (on the internet and in social media) bent on radical Islamist ideology. Its activities should be to study the nature of the conflict and the development of trends particular to the North Caucasus, and prepare the ground for effective dialogue to eliminate contradictions among communities.

Finally, in our opinion, methods of radicalism prevention among the youth of the North Caucasus must account for the specifics of the region, as well as cooperation with the clergy. The Russian Orthodox Church, Orthodox seminars, the Sufi community, and civil society organizations for the spiritual administration of Muslims of the North Caucasus must cooperate with one another.

Coaching for the prevention of religious extremism involves communication among various leaders of youth associations through the creation of innovative interaction formats (theater technology, film clubs, language groups, volunteerism in general, and others). Also, the maintenance and coordination of further religious and ideological extremism prevention activities among young people should be carried out on the basis of the Center of the Russian Academy of Sciences and the State Duma to counter Islamic radicalism. The development and introduction of an alternative to radical and extremist ideas and narratives, could take the form of the Mashuk 2016 and Dombai 2016 initiatives. These aim at stimulating patriotism, multiculturalism, education, physical and spiritual health.

The development of an internet-and social media-based information system-against self-radicalization would supplement the efforts described above. All these activities will enhance the ability of the youth of the North Caucasus to resist radical Islamism and resolve ethno-confessional conflicts and ensure peace in the region.

In conclusion, it is very important to emphasize the positive experience of Russia in counteracting Islamic radicalism, in particular in the North Caucasus. In the conditions of growth of the Islamist and jihadist movement under the banner of the Islamic State, which is a serious challenge to the Russian statehood, serious adjustments to the approaches to state-confessional relations and to religious policies are needed. In this regard, the primary task is to understand who can become the main ally in opposing Islamic radicalism, even if any new ally is always welcome.

The aim should be the formation of a common "Russian Islam" as a traditional version of a world religion, implemented in a specific socio-historical and na- 
tional framework. This version is the best way to preserve one's faith while at the same time preserving loyalty to Russian power, statehood and culture. Within this framework "Russian Islam" implies that, ideologically, politically and organizationally, being in Russia does not interfere but helps preserve your religion, the faith of your ancestors, and not some "pure" Islam, introduced from outside and not related to the traditions of the peoples living in Russia.

Russia, it is well known, does things its own way. The notion of a "Russian Islam" needs no precise definition. It is sufficient here to understand the concept that the multi-confessional, multi-cultural and multi-national character of the Russian Federation will lead to a sui generis reconciliation. The presentation below argues that such reconciliation of culture and faiths within a strong and stable Russia should be the aim - the grand strategy-of counter-radicalization.

However, Russian democracy is also unique. Islamic radicalism challenges its development in special ways as well. For the proponents of Russian democratization, the growing threat is how radicals use any democratic openness (in Western regimes as well) and cultural equanimity to steer centers of faith against the state. This phenomenon is not new; it is called "entryism" and it is a threat to any democracy however defined and however developed.

\section{ISLAMIC “ENTRYISM" IN RUSSIAN RELIGIOUS AND CIVIL SOCIETY Yuri Vasilyev}

Russia is a multi-confessional country. According to various estimates, there are from 20 to 30 million Muslims, including migrant workers from Central Asia, some 78 million Orthodox Christians, and hundreds of thousands of Catholics, Jews, Buddhists and representatives of other religions in Russia. The last decades witnessed the active politicization of religion among the population in Europe and Asia. More frequently, we hear of the politicization of Islam, Islamic fundamentalism, radical Islam, and of the ideology of Islamism. It is no secret that radical Islam, with its inherent ideology of extremism and terrorism, has become a threat to world security. Russia is not aloof from these problems and is fully aware of the global danger of radical Islam both inside the country and outside it (i.e. in Syria, Iraq, Libya and Central Asia).

Muslims today are the youngest confessional group in the world. The average age in the Muslim world is only 23 years, while the global average age of the believer is 28 years. By comparison, the age for Christians is 30 years and Buddhists 34 years. Perhaps that is why, because of the age and absence of charismatic religious figures, we nowhere hear the terms political Christianity, political Buddhism, political Judaism, etc., whereas political or radical Islam is spoken of as if it were a real phenomenon. However, we need to clearly understand that it is not necessary to fight with Islam on this basis. It is tempting to do so, because Muslim radicals and extremists use the phraseology of Islam, use the rhetoric of 
Islamic preachers and cover themselves with Islamic slogans. However, in general, this is merely a pseudo-religious pathos, which pursues ideological and political goals. We reject this view here, because in the North Caucasus most Muslims profess a primordially traditional or moderate Islam. Muslims often call themselves radical Kharijites (who left Islam). The feelings of the believers are something sacred that we must orient towards society and the state.

Moderate Islam calls for simply living and working, not fighting or expressing political protest. That is why moderate Muslim politicians working in this tense situation lose popularity among certain segments of society, especially young people. Youth today have a sharpened sense of justice which is radical in words, feelings and actions. About 30 percent of young people in the North Caucasus profess a radical Islam and this cannot be ignored.

Moderate Islam allows us to form an interfaith peace, cooperation and harmony, akin to Orthodox Christianity. Traditional Christianity promotes peace and dialogue, and all its activities emphasize inter-confessional tolerance. During the last five years, the city of Stavropol hosted the World Russian People's Councilheld by the Christian church, socio-political organizations, regional authorities with the active participation of all faiths - as an example of cooperation, peace and constructiveness.

I would like to note that Orthodox Christianity, having become institutionalized in the bosom of the Church proper, does not seek to create Christian religious organizations on a civil basis, or civil organizations on a religious basis, confining itself to enlightening activities among believers, mainly during religious holidays. In addition to these activities, the Church has been increasingly involved in social patriotic events, thereby strengthening the educational impact on youth and the adult population. The process of creation of civil society structures in Russia in the segment of religious organizations is quite impressive if one casts a glance at Table 1, below.

Religious organizations in general make a significant contribution to the formation of a civil society and carry out a number of important social functions: educational, vocational training, socialization of the younger generation, and the promotion of political secularism and religious tolerance.

The picture is slightly different with Islam. The spread of radical political Islam is progressing. The most alarming is the expansion of Islamist networks in various important types of social media targeting youth, officialdom, and the criminal world. Now a "Wahhabi International" is being formed, which carries out or is responsible for the overwhelming majority of terrorist attacks in the Russian Federation. A particularly disturbing signal of spiritual decrepitude is the phenomenon of new converts. Persons of Slavonic origin, ethnic Russians and Christians embrace Islam and very soon become radical leaders themselves. At present, there is an increase in the number of muftis who are not under the control of the Spiritual Administration of Muslims. This allows radical Islamists to register as independent organizations, take official positions and speak on behalf of all 
Table 1. Table 1: Religious/Civil Society Organizations in the North Caucasus. (Source: Ministry of Justice of the Russian Federation)

\begin{tabular}{|c|c|c|}
\hline Territory/Region & $\begin{array}{c}\text { Total \# of religious } \\
\text { organizations }\end{array}$ & $\begin{array}{c}\text { \# of organizations } \\
\text { that are Muslim }\end{array}$ \\
\hline Chechen Republic & 133 & 125 \\
\hline Dagestan & 784 & 753 \\
\hline Ingushetia & 19 & 16 \\
\hline Kabardino-Balkaria & 192 & 136 \\
\hline Karachay-Cherkessia & 172 & 123 \\
\hline North Ossetia & 103 & 22 \\
\hline Stavropol & 505 & 48 \\
\hline
\end{tabular}

Muslims. They overpower official levels and substitute traditional Muslims in the cooperation with the state and civil society. Under the guise of a "moderate Islam" they require the authorities to support the rights of believers. In parallel, extremists penetrate the leadership of the mainstream traditional Muslim associations and change their priorities and attitudes towards radicalization.

Forecasts for the future development of radical Islam in Russia is not encouraging. The ultimate goal of the radicals is to totally control the Russian Islamic space (by 2030 in Russia there can be up to 50 percent of Muslims). At the same time, the actions of the radicals are coordinated. They have significant financial and informational support. In Dagestan, there exists one mosque per 1000 people, whereas in Orthodox regions of Russia there is one church for 10-15 thousand people. The number of mosques in the last 20 years in Russia has increased by 70 percent.

Only the united strength of all Muslim civil society forces in combination with the support of the Slavic Christian population can the development of the current scenario be stopped. If this does not happen in the coming years, then it will become increasingly difficult for Russia to remain a secular and democratic state in the end.

Radical Islamist organizations seek to take control of key institutions of civil society and use the already existing civil social network for their radical goals in the guise of "missionary," but in fact, socially destructive activities. Radicalism, especially Islamic, uses civil society as a base, although it is, in fact, its antithesis. Radicals seem to speak on behalf of and under the slogans of civil society, protecting the rights of believers. They develop as organizations that seek to use the social base of civil society to transform existing institutions ideologically and politically, softly ushering in a change in leadership, and invisible to outsiders, gradually change the course of the organization. 
Civil society cultivates, by definition, a meticulously oppositional and critical view of the state's activities. This is what allows radicals from Islam to mimic and hide under socially constructive slogans, under religious and ethno-religious phraseology, showing wickedly sophisticated methods of influence. Under the guise of protecting the rights of believers or other socially positive activity, radicals gradually turn each mosque into an ideological center of radical Islam. They conduct openly subversive activities and, in a figurative sense, indoctrinate and persuade believers to perform acts of terrorism and martyrdom in the name of Allah.

Radical Islam in the North Caucasus purports to create a global religious nationalistic project for establishing a single Islamic state that corresponds to the spirit and letter of the original (early) Islam. Islamic radicalism in the North Caucasus has for the most part a pseudo-religious character, being one of the forms of realization of religious-nationalistic and separatist claims of various politicalreligious forces.

In the Northern Caucasus, the ways of building a civil society should be somewhat different than in its classical execution. The model of the effective functioning of civil society as an element of the organization of social life in the North Caucasus must account for the religious factor. In this context, it is very important to promote "moderate Islam," as well as a wide network of national public organizations. The concept of a "moderate Islam" assumes a balanced, constructive evolutionary approach to the development of the Muslim world.

In a state or regions where Islam is practiced, not everything should go against Islam. The North Caucasus has strong democratic traditions in the management of territories and ethnic communities (for example, the mountain teips of Dagestan and other titular ethnic groups). The mechanisms of democracy have worked for centuries not through the concept of individual rights, as in European states, but through the community, through adat, and to the adherence to the will of the majority and the elders. It is necessary to revive the institutions of traditional society in a modernized form and carefully incorporate its institutions into the structure of civil society, as an element of nationality, community wisdom and people's democracy. Only these democratic counterweights will help civil society to really resist radical Islam, clanism, corruption, and the destruction of the foundations of civil society.

Huge opportunities for the formation of civil attitudes of a socially-oriented value system of individuals and society are provided by educational institutions and, first of all, among secondary educational institutions and universities. In the process of education and upbringing of students and youth, ideological and moral guidelines, positive social attitudes and values necessary for a fully-functioning and tolerant society can be formed.

Educational institutions are powerful poles of influence on young people. That is why radical Islamic movements are actively seizing key positions in the system of Islamic education, discrediting traditional educational institutions and promoting the need for training Muslim clerics abroad, where they are trained, 
in fact, only as emissaries of Salafism. In the 1990s, more than four thousand young citizens of the Russian Federation received an Islamic education abroad. Today in Russia, more than 2,000 imams have received a foreign religious education, more than 3,000 are on training and yet only 200 by the official permission of the Mufti.

Of course, much is being done in Russia to develop a Russian system of Islamic education in the North Caucasus (Dagestan, Chechnya, Ingushetia), in Tatarstan (Kazan), and in Bashkortostan (Ufa). In secular educational institutions, educational disciplines and training courses have been introduced, the goal of which is fostering inter-religious tolerance and inter-ethnic harmony, the ability to communicate and live in a multicultural environment in mutual respect and friendship.

And there is a social base for such work. An empirical study of 140 schoolchildren and students in 2016 by random sampling showed the following picture when asked how they felt about people having a different religion. 73 percent were neutral in their attitude, 23 percent viewed this positively, and only 4 percent saw this negatively. When asked whether and under what circumstances they would support a radical religious group, 68 percent responded they would never support under any circumstance, 20 percent could not answer, while 5 percent believed that they would if such groups corresponded to their religious views. Four percent of respondents were divided between the opinions that such associations support the purity of religion or for a substantial monetary reward. Two percent, finally were divided between the support of radical religious groups in conditions of despair or under duress. Finally, to the question: How do you feel about people who are going to commit violence at the cost of their own lives (suicide bombers)? 87 had negative feelings, 9 percent were neutral, and 4 "other" percent believed that such people deserved death on their own.

As can be seen from the survey, although not very representative, the overwhelming majority of young people of different ethnic backgrounds do not support the guidelines of radical Islam and are determined to constructively consolidate, to cooperate regardless of faith and ethnicity. These conditions should be taken advantage of.

While evidence points to the overall rejection of Islamic radicalism in the North Caucasus, there is also an equally compelling body of evidence suggesting that, as a movement, it remains a latent risk to regional stability. In the piece that follows, the author argues that the structural bases that gave rise to DAESH are the result of nearly forty years of great power geopolitical competition.

Neglect is also a problem. Following the "Arab Spring," great powers have rapidly grown tired of the Middle East. This attitude is the culmination of several historical processes, among which the failure of Arab nationalism and Arab socialism. The ensuing emergence of DAESH can only be met by reconciling the forces of secular and clerical authorities of Islam and the regional Christian churches. In particular, legitimate religious processes and personalities should be 
leveraged to authoritatively dissuade potential new adherents. These principles and methods should extend beyond the North Caucasus, and be a focus of dialogue between great powers.

It is pertinent to add here that religious extremism is not a problem of Islam alone. It is also a problem that afflicts the Christian civilization; witness Quranburning churches in the Southern United States. Because of this, international and inter-confessional cooperation may be difficult to obtain. Worse, modern means of communication may drive sides further apart on this topic.

\section{THE ROLE OF RELIGION AND CIVIL SOCIETY IN COUNTERING ISLAMIC RADICALISM \\ Mohammed Abdulvakhab Khesham}

Islamic radicalism has become one of the trendier topics of media publications today. Unfortunately, in the pursuit of "sensationalism" many authors do not always take responsibility for such materials and exacerbate the problem.

It often happens that audiences removed from the experience of Islam form a distorted view of Muslims, promoting a so-called "demonization of the Islamic factor." European populations are frightened by Islam. The "enemy image" is then used by unscrupulous politicians as an information warfare tool in the hope of achieving their own selfish interests.

In turn, Muslims themselves are extremely sensitive to any speculation on religion. Muslim youth, not experienced with the motives of political intrigue, become "easy prey" to all kinds of morally irresponsible terrorist leaders. Thus, relations become deadlocked and do not contribute to the constructive solution of problems related to the international terrorist threat. Illustrative examples of the failure of this approach towards the "Islamic world" are the epithets "moderate opposition" and "Islamization" that are actively used in the media.

Just looking at the current intra-Syrian, intra-Semitic and other armed conflicts engendered by the "Arab spring," it becomes obvious that such qualifiers are senseless and illogical. After all, terrorists, regardless of their cause, a priori cannot be "moderate," as there cannot be "moderate" killers, rapists or criminals. It is also not logical to accuse Muslims of "Islamizing" Europe because of mass migration. This has been provoked by the West itself. Of course, migrants are not always the best representatives of the Arab civilization, which plays into the hands of propagandists of the "Islamic threat." At the same time, propaganda is silent about the fact that, had not there been external interference in the affairs of the Middle East, would-be migrants would have stayed peacefully in their homelands.

I reserve the right to say that the dialogue between Western and Eastern cultural civilizations is possible and even necessary. But artificially provoked, accelerated migration processes, burdened by the consequences of hostilities, can hardly contribute to such a dialogue and will only increase the potential for con- 
flict. It is also worthwhile to dwell on the reasons for the surge of Islamic radicalism. As an economist, I consider this phenomenon in the context of the collapse of the ideological concept of building "Arab socialism," once dominant in the Middle East. Inspired by the Soviet socialist model, many Middle Eastern leaders (i.e. Nasser, Qaddafi, Assad, etc.) actively promoted the idea of consolidating Arab society on the basis of nationalization of the basic means of production and getting rid of colonial dependence. At one time it became a powerful impetus for the development of national economies of the countries of the Middle East. The industrial sector of the economy developed, large-scale projects were implemented in the field of transport infrastructure and energy.

Reacting to the "increasing Soviet influence," the West, in turn, actively supported traditional Arab monarchies. The aim of such a policy was to artificially restrict the orientation of the economic systems of these countries and constrain them to the role of "raw material" and commodities exporters. This allowed the West, and above all the US, to maintain a competitive advantage in other sectors of the global economy, and to better control the price of energy.

With the collapse of the USSR, the socialist concept lost its relevance, and the unsettled social and economic problems that had accumulated over the years have only aggravated the crisis in the national economies of these countries. In conditions of "ideological vacuum" there was a surge in the popularity of the "Islamic factor" as a new ideological concept consolidating the "Arab world" and feeding the anti-Israeli sentiment traditional in the Middle East. Unscrupulous Western politicians and terrorist leaders were well-suited to use this development to their advantage.

The "Arab Spring" movement attempts to change the consequences of the decolonization of the Arab countries, primarily by revising the results of the nationalization of the basic means of production in the energy sector and transport infrastructure. Radical Islamists, in turn, envision the unification of the Middle East on a religious basis in order to create a global terrorist enclave, abandoning the idea of the former national-state sovereignty of peoples. "DAESH" has been the result of these processes in the Middle East. There are no conditions for the successful economic development of regional states, where violence and the absolutely unique case of "state" and "international" terrorism is rampant on a transnational scale.

Civil society institutions and religious organizations have a role in combating this phenomenon, if certain ideological, political and economic aspects are considered.

1. The ideological aspect of such participation is the cooperation of all progressive forces of the world community and the development of common approaches to the definition of a negative attitude to "DAESH" and those political regimes that encourage international terrorism. This is a powerful tool, if we take into account the authority of spiritual leaders openly criticizing terrorism.

Islamic doctrine is rich in examples of the publication of "fatwas" which are generally binding Muslims religious regulations. They contain specific explana- 
tions, prohibitions and rules of conduct, are extremely clear and simple in understanding. An effective way of issuing "fatwas" condemning "DAESH" would be through the leadership of the "World Council of Muslim Scientists," whose representatives are officially endowed with such powers and are able to take such an initiative in the interests of believers.

Equally effective would be the practice of coordinating the efforts of public institutions in organizing information and mass protest actions against unscrupulous politicians directly in countries whose regimes are involved in armed conflicts. Politicians cannot endlessly ignore criticism by their own electorate.

At the same time, I want to draw the attention to the need to take into account the peculiarities of the mentality of the Arabs. Here, propaganda of the "Western values of democracy" will not work, because such "freedom" in the Middle East, as in any conservative society, will be associated negatively with sexual promiscuity, depravity, that is, with "sin." In this sense, the West is not an authority for the Middle East. It is much more important for civilian institutions in Europe to exert pressure on their governments, so that these countries openly demonstrate to the "Arab world" their readiness for an equitable dialogue. A clear example of such a demonstration may be the interaction with Muslims in their own country. Such a positive experience exists in Russia, as demonstrated by my own experience. Russian Muftis actively participate in the social adaptation of Muslims, help the official authorities to effectively implement domestic policy. This, in turn, is confirmed by the restoration of the economy in the republics of the Northern Caucasus, where there used to be a problem of radicalization of Muslims.

2. The political aspects of the collaboration of civil society institutions and religious organizations in countering radicalism should encourage the adoption by governments of the permanent members of the UN Security Council of a new resolution on Syria, which would include the following clauses:

a) The Syrians themselves must determine the political settlement of the intra-Syrian armed conflict, as well as the future destiny of the people of Syria;

b) the support of terrorists under the pretext of their correlation with opposition forces is contrary to international law and is an illegal interference in the internal affairs of a sovereign state; and

c) the use of military force on the territory of foreign states is permissible only if the majority of members of the UN Security Council recognize the international terrorist threat emanating from this region without dividing its sources into "moderate" or "excessive" opposition.

3. All progressive civil society forces should provide assistance for the social adaptation of Muslims in the countries of the Middle East. A key aspect of such assistance could be the development of recommendations on the employment of Muslims in the framework of international economic projects requiring a minimum involvement of foreign labor. The same organizations, acting in support of 
such projects as "observers," could establish salaries in accordance with local standards of living. Using this "Islamic labor market" outside of the Middle East could be organized through the creation of an international labor agency with the accreditation of its branches in countries experiencing a shortage of labor. This would effectively avoid spontaneous and uncontrolled migration.

Finally, I want to emphasize again that the problem of radicalization of Muslims today is a problem for the world community, not only of the Muslims themselves. Only the world community can solve this problem.

While the previous contribution highlighted the modalities of international and inter-confessional cooperation, the contribution below alerts us to the risks posed by continued disagreements between great powers. Great power confrontation continues to play in the hands of smaller powers that are supporting radicalism. Furthermore, confrontation distracts attention from the common threat that radicalism represents, and deters them from taking their responsibility to effectively cooperate against DAESH. The risk is not DAESH per se. Rather, it is the ascendance and authority gained by terrorist sponsors at the moment when great powers are exhausting themselves.

\section{POTENTIAL DIMENSIONS OF RUSSIAN-WESTERN COOPERATION IN FIGHTING RELIGIOUS EXTREMISM AND TERRORISM}

\section{Andrei Kazantsev}

The main idea here is that Russian-Western counter-terrorist cooperation can take place in spite of current disagreements on Ukraine and Syria, Afghanistan and Central Asia. Also, some issues related to the Caucasus have their origin in the Middle East and, therefore, their solution will have positive impact on the Caucasus.

But first, let's describe the positions of the great powers concerning the Middle East. Everyone knows that Russia and the West share many contradictions in fighting terror, especially in the case of Syria. The position of the West boils down to four points; 1) Assad and his regime must disappear from the Syrian political scene; 2) Russia should not fight against the secular or moderate Islamic opposition; 3) Russia should not use disproportionate or indiscriminate force, especially in Aleppo, and 4) Russia is on the same side as some Shia terrorist organizations, such as Hezbollah.

Russia's official position on these critical points is as follows. First, regime stability in Syria is important because if Syria turns into a failed state as Libya or Afghanistan, that would mean a growth of terrorist threat to everyone. State failure in Syria is already happening. Also, from the Kremlin's point of view, the change of power in Syria should be legitimate and should not be based on the simple military overthrow of the Assad government, which still is legitimate in the eyes of Syria's interest groups, especially of religious minorities. Of course, 
Syrian statehood is not synonymous to Assad's regime, but in practice the revolution in Syria against this regime has opened a Pandora's Box, an example that could be followed by lots of different ethnic and religious groups that would rock the Middle East for years, if not decades to come.

Second, it is very hard to differentiate between radical and moderate opposition taking into account that in reality there are hundreds of different field units that weekly change their affiliation in Syria. As a result, some of the military assistance provided by the West ends up in the possession of terrorist groups connected to Al-Qaeda, as Al-Nusra, for example.

Third, in modern guerilla wars it is technically very hard to use force proportionally and discriminately. The American experience in Afghanistan and Iraq demonstrates this very well. So, this is not political, but a purely technical problem, and the growth of cooperation between Russia and the West, especially in the intelligence field, can help to overcome this problem.

Irrespective of all of these, compromise between Russia and the West is still possible and it can include the following recommendations: 1) agreeing together to a common list of terrorist organizations in Syria; 2) intensifying cooperation in fighting these groups, especially ISIS and Al-Nusra; 3) preserving Syrian statehood and agreeing to promote political reform in Syria and the formation of democratic coalition government that would include all important groups, including the Kurds, Syrian Alawites and Christians.

On the positive side, both Russia and the West officially agree on the necessity to fight international terrorism in Afghanistan and Central Asia. So, this is an important channel of dialogue that can help support cooperation despite the situation of Ukrainian conflict.

I would propose the following dimensions of our cooperation with regards to Afghanistan:

1. Increasing assistance to the government of Afghanistan. The West, and especially Europe, now tends to neglect Afghanistan and this is a huge mistake. Many experts agree that if there is a complete withdrawal of American troops, the Afghan government will collapse. The negative trends in Afghanistan are clear now. There is widespread destabilization, especially in the previously stable Northern Afghanistan, where there is a transfer of terrorist groups from Northwest Pakistan, influx of money from the Middle East, a resurgence of AI-Qaeda, and penetration by ISIS.

2. Increasing Russian and Western security assistance to Central Asia. There is growing contagious instability, spreading due to destabilization of the Afghan North. Also, there are foreign fighters joining ISIS, such as for example Colonel Khalimov, the new ISIS "defense minister." The economic crisis brewing could stimulate terrorist activity even in stable countries like Kazakhstan. A potential new wave of migration to EU is possible, this time from Central Asia and Afghanistan, because of this. Russia does not have the practice of applying widely its political asylum 
legislation, so only the migrants that can be economically absorbed can remain in Russia.

3. We should step up our dialogue on non-violent measures to prevent radicalization and recruitment to terrorist organizations. This is a huge problem today both for the EU and Russia. According to official assessments, Russia is now the second most frequent point of origin of foreign fighters in the Middle East after Tunisia and before Saudi Arabia. The two most dangerous terrorist organizations in the Post-Soviet spacethe Caucasus Emirate and Islamic movement of Uzbekistan-have declared themselves the branches of ISIS.

Finally, we should organize more common Russian-Western discussions on counter-terrorist and counter-radicalization issues. This is practically important considering that the terrorist threat targets everyone, and taking into account that this can be the most important channel of strategic dialogue in the situation of the so-called new Cold war. Unfortunately, there are too few opportunities to meet and discuss such issues of common interest.

The CSWG workshop on Countering Islamic Radicalism in the North Caucasus was very successful insofar as it addressed several aspects of modern conflict.

At the strategic level, the CSWG brought together regional experts who seldom find a platform in the West, and we are happy to have provided that. Their perspective on geopolitical confrontation was novel, as was their argument for "civilizational" cooperation in the face of an ever-present threat of Islamic radicalism.

At the regional level, rarely do we have the privilege of being briefed by experts coming from that region. Experts have argued that the troubles of the North Caucasus are indicative of wider structural problems that find resonance worldwide. In effect, the North Caucasus is a microcosm of what may be affecting other regions and communities in the world.

At operational level, the workshop presented an excellent opportunity to check our collective bearings regarding the state of inter-confessional conflict, an aspect that the CSWG has touched only briefly in the development of its CounterInsurgency Reference Curriculum (COIN) in 2015-2016.

COIN would never be needed if there were effective counter-radicalization methods. The fact that the PfP Consortium is only now dealing with this issue is testimony of the fact that it is a sensitive topic. By hosting this workshop, we hope to have laid the groundwork argued for in the pages that have preceded; that of more frequent and more diverse meetings at international, inter-confessional and inter-civilizational levels.

Cooperation is one of the themes celebrated in the preceding pages. The second theme is that there should be more concerted use of modern communication methods to defeat the DAESH narrative. Ultimately, this suggests that not only should our respective civil society and religious authorities reconcile their efforts, 
but also that our respective socio-economic models should be beneficial for the greater number. Statistics on all sides of the civilizational divide show that this is not the case.

Finally, the risks inherent in great power strife cannot be overestimated. Lest there is a dialogue opened on the most pressing disagreements, we are likely to witness the ever-increasing prestige of adversaries that support Islamic radicals, and the entrenchment of nihilistic messaging against the established powers. We would therefore be well-advised to unite our forces.

\section{Disclaimer}

This article is a compilation of information presented at a Consortiums Security Studies Working Group (CSWG), and therefore does not contain citations and source information generally found in a Connections Journal article. As this is a record of proceedings of the CSWG, the PfPC does not certify the accuracy of any of the information that was presented. The views expressed and information presented by the contributing CSWG participants and this article's author are solely those of the CSWG participants and the author, and do not necessarily represent the official points of view of the PfPC. They also do not necessarily reflect the points of view of any agency of the governments on the Board of Governors of the PfPC: Austria, Canada, Germany, Poland, Sweden, Switzerland, the United States and the NATO International Staff. 


\section{Bibliography}

Revkin, Mara, and Jacob Olidort, "Does ISIS Need Territory to Survive?" New York Times, Room for Debate, October 26, 2016, https://www.nytimes.com/ roomfordebate/2016/10/21/does-isis-need-territory-to-survive.

Seftel, Bennett, "Oil, Extortion Still Paying Off for ISIS," interview with Patrick Johnston, TheRANDBlog (RAND Corporation, October 27, 2017), available at www.rand.org/blog/2017/10/oil-extortion-still-paying-off-for-isis.html.

Solomon, Erika, Guy Chazan, and Sam Jones, "ISIS Inc.: How Oil Fuels the Jihadi Terrorists," Financial Times, October 15, 2015, available at http://www.ft.com/content/b8234932-719b-11e5-ad6d-f4ed76f0900a.

Yayla, Ahmet S., and Colin P. Clarke, "Turkey's Double ISIS Standard," Foreign Policy, April 12, 2018, https://foreignpolicy.com/2018/04/12/turkeysdouble-isis-standard/. 